\title{
The green revolution as a process of global circulation: plants, people and practices
}

\author{
JONATHAN HARWOOD
}

KEYWORDS: Green Revolution, circulation, contact zones, indigenous knowledge.

JEL CODES: N50, O13, O31, Q16.

he "Green Revolution" (GR) is often portrayed as a humanitarian develop-
ment programme in which crop varieties, cultivation practices and expertise
were transferred essentially from global North to South. In this paper, however, I argue that this picture is seriously misleading for two reasons. First, it overlooks the significance of circulation between these regions. Several of the innovations central to the GR's high-yielding varieties of wheat and rice, for example, originated in the global South before being taken up by northern breeders, while important practices and experts were transferred between countries within the global South. Moreover some of the approaches to increasing smallholder productivity which emerged from the 1970s can be traced to encounters between northern experts and southern farmers dating from the colonial period. In view of these patterns of circulation, the GR is more accurately depicted as a collective undertaking than as a "heroic" achievement of the North. Second, the tendency to represent the GR -and development aid more generally - as a "gift" from the benevolent North to the needy South ignores the very substantial economic gains which have accrued to northern agriculture and industry by virtue of GR research nominally intended to benefit the South. 


\title{
La revolución verde. Un proceso de circulación global: plantas, personas y prácticas
}

\author{
PALABRAS CLAVE: Revolución verde, circulación, zonas de con- \\ tacto, conocimiento indígena.
}

\section{CÓDIGOS JEL: N50, O13, O31, Q16.}

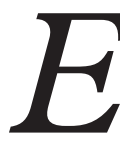

s frecuente que se presente la Revolución Verde (RV) como un programa de desarrollo humanitario que supuso la transferencia de variedades vegetales, técnicas de cultivo y conocimiento desde el norte hacia el sur. En este artículo, sin embargo, argumento que esta es una imagen falsa, por dos motivos. Primero, porque ignora la importancia de los fenómenos de circulación entre aquellas regiones. Algunas de las innovaciones más importantes de la RV,por ejemplo aquellas que permitieron la obtención de variedades altamente productivas de trigo y arroz, tuvieron su origen en el sur, antes de ser adoptadas por investigadores del norte. Del mismo modo, dentro del propio sur existían redes activas de circulación de prácticas y expertos. Tanto es así, que el origen de muchas de las prácticas puestas en funcionamiento en la década de 1970, para incrementar los rendimientos de pequeños propietarios, puede remontarse hasta los primeros intercambios de información entre expertos del norte y agricultores del sur durante la época colonial. Teniendo en cuenta estos patrones de circulación, es pues más adecuado presentar la RV como un proyecto colectivo que como una acción heroica por parte del norte. En segundo lugar, la tendencia a presentar la $R V$-y la ayuda al desarrollo en general-como un "regalo» del norte al necesitado sur, ignora los grandes beneficios económicos obtenidos por los sectores agrícola e industrial del norte como consecuencia de la RV, que era supuestamente un mecanismo concebido para el beneficio de los países del sur.

Received: 2016-07-12 • Revised: 2017-05-02 • Accepted: 2017-05-10

Jonathan Harwood [orcid.org/0000-0001-8272-5416] is Emeritus Professor of the History of Science and Technology at the University of Manchester and Visiting Professor at the Centre for History of Science, Technology and Medicine, King's College London. Address: King's College, London WC2R 2LS (United Kingdom). 


\section{INTRODUCTION}

The Green Revolution (GR) is often portrayed as a humanitarian development programme in which crop varieties, cultivation practices and expertise were transferred essentially from global North to South. In this paper, however, I argue that this picture is seriously misleading for two reasons. First, it overlooks the significance of circulation between these regions. Several of the innovations central to the GR's high-yielding varieties of wheat and rice, for example, originated in the global South before being taken up by northern breeders, while important practices and experts were transferred between countries within the global South. Moreover some of the approaches to increasing smallholder productivity which emerged from the 1970s can be traced to encounters between northern experts and southern farmers dating from the colonial period. In view of these patterns of circulation, the GR is more accurately depicted as a collective undertaking than as a "heroic" achievement of the North. Second, the tendency to represent the GR -and development aid more generally- as a "gift" from the benevolent North to the needy South ignores the very substantial economic gains which have accrued to northern agriculture and industry by virtue of GR research nominally intended to benefit the South.

Although historians have not usually viewed the GR from the perspective of global history, no one will doubt that it was a global phenomenon. As an agricultural development programme devised in the US and introduced in the developing world after 1945, for example, the GR was a meeting-ground for northern experts and southern farmers. The question I pose in this paper is what kind of global phenomenon was it?

Given its declared aim of alleviating poverty and hunger, the GR looks on the face of it to have been a humanitarian undertaking which originated in the North and was transferred to the South (e. g., Jennings, 1988; Anderson, Levy \& Morrison, 1991; Perkins, 1997). The first of its programmes was designed and funded by the Rockefeller Foundation, began in Mexico in 1943 and served as a model during the 1950s for programmes elsewhere in Latin America and in India. In 1949 the United States government launched a similar policy of "technical cooperation" which provided technical assistance (on agriculture among other things) to countries in the global South. During the 1950s the Ford Foundation also began to fund rural development in India and elsewhere, and by the 1960s and '70s GR programmes had been established in many Asian countries, funded predominantly by northern foundations or governments.

Central to these programmes was the belief that hunger could be eased by increasing the food supply through more efficient production. Thus GR programmes typically offered a "technological package" which promised big increases in crop yields (primarily 
of cereals such as maize, rice and wheat). The package on offer (improved plant varieties, commercially produced mineral fertiliser and pesticide as well as mechanization) was very similar to the technology which had already been introduced in North America and western Europe from the late $19^{\text {th }}$ century. And since developing countries after 1945 generally lacked the capacity to produce either fertiliser or tractors, the technology initially provided by the GR was generally manufactured by western firms. The high-yielding cereal varieties central to the package, though not of commercial origin, were produced using methods developed at American universities or by United States breeders working in GR programmes.

To be sure, technical support from the North was envisioned as a temporary measure. Eventually such expertise was to be provided by scientists from the host countries, and to make that possible many of the early programmes included an element of training. In Mexico, for example, the Rockefeller Foundation provided fellowships so that promising young Mexican agronomists could receive research training at United States universities before returning home to assume positions at Mexican agricultural colleges or experiment stations. During the 1950s, similarly, the newly independent Indian government asked for-and received-the Foundation's help in strengthening what was then regarded as a rather small and inadequate system of agricultural research, education and extension. Thus although southern experts were eventually to take over responsibility for the GR, they were largely trained in the North where they learned a US approach to boosting agricultural productivity.

In terms of planning, funding, technology and personnel, therefore, the GR might easily be mistaken for an aid programme which was transferred from North to South. In this paper, however, I will argue that this view of the GR is seriously misleading for two reasons. First, the technology of the GR was not devised solely in the North. If one looks at the patterns of circulation (of plants, practices and people) they do not reveal simply oneway traffic from North to South but instead a circulation in many directions. And since that circulation prompted the formation of new and important knowledge, the GR should be seen as a collective achievement by both North and South. Second, despite appearances, the GR is not best represented as a "gift" from North to South, for northern agricultural interests appear to have gained substantially from these programmes.

\section{CIRCULATION}

The concept of circulation (of things, people, knowledge) is central to global history. Although sometimes referred to as flow or movement, the key point about circulation is that 
it designates a process of movement back and forth between regions rather than one-way diffusion (Raj, 2007, 2013). Some have suggested that historians of science and technology have been relatively slow to enter the historiographical discussion about global or transnational history (Turchetti, Herran \& Boudia, 2012). Over the last decade or two, however, quite a few authors have begun to use the concept of circulation in order to illuminate problems in the history of science (Secord, 2004; Sivasundaram, 2010; Roberts, 2009: $28)^{1}$. Nevertheless, the historical literature on the GR contains as yet remarkably little discussion of circulation. In this paper, however, I will suggest why circulation deserves more of our attention.

Let us begin with the origin of the high-yielding cereals varieties so central to the GR. Take the case of wheat. As is well documented, the wheat varieties which proved so successful in India, Pakistan and elsewhere in South Asia during the 1960s and '70s had been developed as part of the Rockefeller-funded Mexican Agricultural Program during the 1950s (Dalrymple, 1986a). The person who is usually credited with this achievement is the American breeder, Norman Borlaug, who was awarded a Nobel Prize in 1970.

Perhaps because of his fame, some accounts of Borlaug's work (e.g., Willis, 2006) fail to mention that the short type of wheat ${ }^{2}$ which he set out to improve -and which later proved so successful- did not originate in the United States nor anywhere else in the North. Moreover by the time Borlaug began to work with short varieties, they had been known for nearly a century, and had already been used by others to breed successful highyielding wheats.

Let us, therefore, trace the route by which Borlaug obtained this key raw material (for an overview, see Perkins, 1997: 210). In 1953 he had received a short variety from a US breeder working at Washington State University, Orville Vogel (Kihara, 1983: 13) and began to use it as a parent in crosses with various Mexican varieties (Athwal, 1971) ${ }^{3}$. Thus Borlaug received his breeding-material from the North, but where did Vogel himself get this short variety? Vogel's source was an American agricultural scientist who had been in

1. Indeed, some now regard "circulation" as a buzzword in history of science which is being used too loosely (FAN, 2012), though this criticism seems to rely on an unduly literal interpretation of the term.

2. Breeders distinguish between dwarf, semi-dwarf and tall wheat varieties on grounds of height. Although some of the varieties bred in the GR, technically speaking, were dwarfs and others semidwarfs, for simplicity's sake I will refer to all of them below as short varieties.

3. The strategy was to make "hybrid" offspring which would have useful traits from both parents. In this case the desired offspring would have the short stature of the Japanese parent and be better adapted to local conditions like the Mexican parent. 
Japan serving as agricultural advisor to the US Army after the war. While there he noticed a strikingly short variety (Norin 10) growing at an experiment station and brought it to the US in 1946. The following year he made it available to breeders, one of whom was Orville Vogel (Reitz, 1968; Dalrymple, 1986a: 13), who began to cross this Japanese variety with various US varieties in order to develop one suitable for US growing conditions (Athwal, 1971). So effective were the varieties derived from this Japanese parent that by the 1980s it had become the major world source of genes for short stature in wheat (Dalrymple, 1986a: 13).

And what is known of this Japanese variety's origins? Short wheat varieties appear to have existed in Japan since at least the 1870 s because in 1873, while leading an agricultural advisory group visiting Japan, an American Commissioner of Agriculture was much impressed by the extremely short wheats he observed in a field, concluding that The Fapanese farmers have brought the art of dwarfing to perfection (quoted in Dalrymple, 1986a: 11) ${ }^{4}$. It is not clear whether the Commissioner brought such varieties to the US or distributed them to breeders there, but in view of the subsequent history of the GR, it is ironic that into the 1940s US wheat breeders took little interest in these Japanese varieties, believing that only tall wheats had the potential for high yield (Dalrymple, 1988: 26-27). Elsewhere in the North, however, the reception was more enthusiastic. French breeders, for example, introduced short varieties from Japan already in 1867, and by 1880 they were regarded as among the best wheats in the country (Dalrymple, 1986a: 11-12). In Italy, too, the wheat-breeder Nazareno Strampelli obtained a short variety from Japan in 1911, crossed it with a local variety, and produced the first of a series of high-yielding varieties which revolutionised Italian wheat-breeding after 1918 (Iori, 2011) ${ }^{5}$. Furthermore, one of Strampelli's varieties played a key role in the development of Mexican GR wheats, and in the 1980s Italian varieties were grown in several north African countries (Dalrymple, 1986a: 13). Thus the starting material for Norman Borlaug's influential work owed its existence to the skill of Japanese farmers a century earlier.

The story with rice was similar. The most famous of these -again, very short- varieties, IR-8, was developed at the International Rice Research Institute soon after its founding in 1962 (Anderson, Levy \& Morrison, 1991). But both of IR-8's parents were of East

4. Whether these short varieties first emerged in Japan is unclear. The particular short variety given to Vogel in 1946 (Norin 10) had been bred in Japan in 1935 (KIHARA, 1983: 13; ATHWAL, 1971: 9), but one of its parents was a short variety which may have come in the $19^{\text {th }}$ century from Korea (DALRYMPLE, 1986a: 12; KIHARA, 1983: 18). Moreover, very short wheat varieties were also known to Indian breeders at the start of the $20^{\text {th }}$ century (PERCIVAL, 1921: $321 \mathrm{ff}$ ).

5. By 1934 Strampelli's wheat varieties accounted for $80 \%$ of the Italian acreage planted in improved varieties (D’AMATO, 1989: 161). 
Asian origin. One of them (Peta) was a tall, disease-resistant variety from Indonesia which had been developed by Dutch breeders in the late 1930s (Barker \& Herdt, 1982: 430). The other (Dee-geo-woo-gen) was a short native (i.e., farmer-bred) variety which was observed at Taiwan's experiment station in 1906 (Athwal, 1971: 12) ${ }^{6}$. In fact, many of the short, high-yielding varieties important for IRRI's breeding programme had been bred at Taiwanese experiment stations. One of these was Taichung Native 1 (Athwal, 1971, 5), which was released in 1956 (Barker \& Herdt, 1982) and was very popular in Taiwan by the 1960s (Athwal, 1971:5-6) ${ }^{7}$. Thus although IRRI was funded by northern foundations and staffed initially by scientists predominantly from the North, the all-important raw material for its breeding programme came from countries in the South ${ }^{8}$.

That key breeding material actually originated in the South and was transferred to the North, however, is only half of the story. As historians of colonial science have emphasised, the circulation of objects, knowledge and practices in colonial empires did not take place solely between the European "centre" and the southern "periphery". Instead transfer also occurred within the global South ${ }^{9}$. In the early $20^{\text {th }}$ century, for example, Cuba's experiment station imported sugarcane varieties which had been bred in Barbados, Java, Jamaica and Mexico (McCook, 2002: 57-58) while Puerto Rican scientists introduced coffee varieties from the Philippines, Hawaii, Java and Ceylon (McCook, 2002: 69, cf. 77). Knowledge of cocoa cultivation-practices, too, spread not only within the British Empire but also to German Africa (Ross, 2014: 55). A similar pattern of circulation applied to rice-breeding. When Japanese breeders began work in Taiwan (following colonization in 1906), they brought with them short Japanese rice varieties with the aim of adapting them to the Taiwanese climate ${ }^{10}$. And in interwar Bengal rice breeders obtained varieties from the Philippines, Guyana and Nigeria (Anderson, Levy \& Morrison, 1991: 239). Follow-

6. Some evidence suggests that this variety may have been derived from varieties brought from mainland China several hundred years earlier (DALRYMPLE, 1986b: 17).

7. High-yielding short rice varieties were also known in Japan from the 1870 s but were unsuitable for most of Asia because: a) they were adapted to temperate conditions; and b) they were of the $j a$ ponica type not valued by most consumers in South and Southeast Asia (FrANCKS, 1984). Taiwanese short varieties, by contrast, were adapted to semi-tropical and tropical conditions which prevailed throughout much of this region and they were of the indica type preferred by consumers there.

8. Although policy-makers or publicists who think that the GR was made in the North might be surprised to learn this, no plant-breeder would be. As a general rule, breeders -then as now- are avid collectors of plant material from anywhere in the world so long as it looks promising as raw material.

9. The pattern of circulation during the colonial period has been aptly described by Fan as a web rather than a single wheel with a hub (2007: 215).

10. This pattern of circulation applied, of course, not just to breeding practices. The Japanese emphasis on cooperatives, extension and commercial fertiliser was also transferred during the colonial period to Taiwan and thence in the " 50 s and ' 60 s from Taiwan to Vietnam and elsewhere in Asia (LIN, 2015). 
ing decolonization such borrowing continued; some Indian wheat-breeders in the $1940 \mathrm{~s}$ and '50s, for example, used varieties obtained from Kenya (Jain, 2010: 82). Given this long history of South-South transfer, it is hardly surprising that it subsequently played an important role in the GR. Most notably, the high-yielding wheat varieties introduced in India and Pakistan during the 1960s had been developed in Mexico a decade earlier ${ }^{11}$.

But plant varieties were not the only things which circulated within the South; cultivation practices did as well. During the 1950s, for example, Indian agricultural scientists spoke of an Indian rice revolution, driven by the introduction from Japan of improved ricegrowing practices (Glover, 2013). During the early 1960s Taiwanese breeders introduced short rice varieties to Sierra Leone and demonstrated how double-cropping could be done in swampy areas (Richards, 1997:210). And in the 1940s and '50s agricultural scientists in Sri Lanka learned during visits to Tanzania about the importance of ecologically distinct rice-growing zones (thus necessitating different cultivation practices) (Pain, 1986: 760-61). When it comes to mechanisation, South-South transfers continue to be significant. Some experts argue, for example, that the key to Bangladesh's GR since the 1970s has been the introduction of small two-stroke engines from China (Stephen Biggs, pers. comm. $)^{12}$.

Of course, cultivation practices are not self-explanatory. In order for them to be successfully transplanted, experts had to accompany them. Between the late $19^{\text {th }}$ century and the Second World War European agricultural scientists often found employment in colo-

11. The high-yielding maize varieties introduced to India by Rockefeller breeders during the 1950s were also from Mexico. And during the 1960s Indian rice-breeders made much use of a short Taiwanese variety (ATHWAL, 1971: 18-20).

12. Since agricultural expertise from the global South has clearly played a substantial role in the genesis of GR varieties and practices, it could be instructive to look at the southern institutions in which such expertise was developed. Unfortunately, however, our knowledge of these institutions is still quite limited. Apart from some work on Mexico (MATCHETT, 2006; CotTER, 2003) and a substantial literature on Japan (see above), evidence from other countries is fragmentary. In countries like India, Indonesia, Sri Lanka or Bangladesh, not surprisingly, the agricultural research institutions which existed prior to the GR were largely colonial in origin (PERKINS, 1997; MAAT, 2001; Pain, 1986; Anderson, Levy \& Morrison, 1991; on rice research in various countries, see BARKER, HERDT \& Rose, 1985; DALRYMPLE, 1986b). Significantly, the approach taken to breeding in several of these places was strongly attuned to geographical variation in agroecological conditions, and southern agronomists were accordingly sceptical of the GR's allegedly "universal” varieties (BARANSKI, 2015). Since most histories of the GR have paid little attention to southern expertise, there has been an unfortunate tendency to portray the GR approach to cultivation as the only realistic way to boost agricultural production at that time rather than as a contested imposition from the North. I hope to address this issue elsewhere (Harwood, "Rethinking the historiography of the Green Revolution", in preparation). 
nial agricultural services ${ }^{13}$ where they devoted their time, for the most part, to increasing the productivity of export crops and supporting large-scale development schemes. When such schemes failed -as they often did-, some of these scientists began to question the prevailing assumption that indigenous cultivation practices were "backward" and instead developed a respect for the rationality of peasant farming, calling for more research on these practices (Beinart, Brown \& Gilfoyle, 2009; cf. Harwood, 2012: 129-30). During the period of decolonisation after 1945, many of these experts returned to the northern hemisphere where they found employment at the World Bank, FAO and other development organisations (Mehos \& Moon, 2011).

Once one takes these patterns of circulation into account, the GR becomes less a "heroic" achievement of northern expertise than a collective undertaking whose resulting varieties and practices drew upon the resources of both South and North ${ }^{14}$.

\section{INNOVATION}

As various global historians have shown, patterns of circulation are important because they bring cultures into contact, making learning possible but also prompting the formation of new knowledge. The spaces in which these encounters take place (above all those between scientists from the North and experts and/or farmers from the South) have been called contact zones (Pratt, 1991; Roberts, 2009: 20) or cultural borderlands (Fan, 2007) ${ }^{15}$. Even where the two cultures are highly unequal in respect of power (e.g., under colonialism as well as since 1945 in development projects), contact makes learning -on both sides- possible, in which case circulation brings the learner back home a little wiser ${ }^{16}$. The

13. In interwar Britain the single most important source of employment for newly graduated biologists was the Empire (KRAFT, 2004).

14. In an ideal world this kind of circulation might have meant that experts' colonial experience would come to inform northern agencies' development policy. Unfortunately, the evidence suggests otherwise. Several of these experts evidently looked on in disbelief as post-1945 development programmes ignored colonial experience and proceeded to make the same mistakes all over again (Hodge, 2010; FREY \& KunKel, 2011). On the apparent inability of the development industry to learn the lessons of its own history, see HARwOOD (2013).

15. A related concept which has been influential in social studies of science is that of trading zones (GALISON, 1997: 803). Although Galison used it to characterise the interactions among groups of experts, Pamela Long has usefully extended the concept to include interaction between artisans and learned men (LONG, 2015).

16. Historians of colonial science, technology and medicine have drawn attention to the role of $i n$ termediaries (e.g., merchants, doctors, surveyors, missionaries, colonial officials) who often facilitated contact and exchange (see, FAN, 2007; SIVASUNDARAM, 2010: 158; HABERMAS, 2013), and it is likely that such figures have also been important in post-colonial development projects. Gorman and others 
point is that culture is not simply transferred and absorbed as is; instead people and things are transformed through the process of culture-contact (Raj, 2007, 2013; Roberts, 2009; Habermas \& Przyrembel, 2013). If parts of one tradition are appropriated by the other, novel hybrid forms of knowledge or practice may arise (Pratt, 1991; McCook, 2002; Fan, 2007: $215,228-29)^{17}$.

How, then, might this perspective be applied to the GR? This is a far-reaching question which cannot be thoroughly dealt with here, but I will outline what an answer might look like by focusing upon just one phase of innovation during the GR.

As is well-known, the GR came in for considerable criticism from the late 1960s for failing to meet the needs of small resource-poor farmers. From the 1970s on, however, substantial attempts were made to develop new approaches to agricultural development which were tailored more closely to the needs of smallholders (Harwood, 2012: 137). Common to these approaches were a few principles:

a) Look closely at peasant-farmer practices as well as to the ecological and economic contexts in which they have to make a living.

b) Listen to what farmers say (about what practices work and what they need).

c) Use scientific theory to improve existing practices rather than introducing a radically different system (e.g., from the North) ${ }^{18}$.

One of these new approaches was farming systems research (FSR). As the term implies, FSR starts from the premise that farming cannot be adequately understood if the ana-

have developed a potentially useful analytical scheme for thinking about the ways in which such figures mediate between experts and laypeople (Gorman, 2010; Collins, Evans \& Gorman, 2010).

17. Fusions of this kind are not peculiar to the cultural encounters of South and North. There is now an extensive literature on the formation of hybrid forms of knowledge -within the northern hemisphere alone- which suggests that the fusion of lay and expert knowledges has been an important historical phenomenon (ASH, 2010; KLEIN, 2012). More recently studies of technical innovation have warned against the view that innovation is driven mainly by formal research and development. Whenever new technology is introduced from the laboratory, it is usually unsuccessful until modified -or improved- by those on the factory floor who have intimate knowledge of the production process (BELL, 1979; FREEMAN, 1994).

18. It has often been pointed out that a similar strategy of innovation was successfully pursued in late $19^{\text {th }}$ century Japan. Finding that western technology was usually inappropriate for Japanese conditions, Japanese experts chose instead to start with indigenous technologies and improve them, albeit by applying western scientific principles (e.g., OHNO \& OHNO, 1998: 12-15). 
lyst focuses narrowly upon the cultivation of a single crop. For every farm actually operates as a system of interconnected parts, including crops, animals and -often- trees but also climate and growing conditions, the economic context, and social and cultural meanings attached to farming. If one wants to increase the productivity of the farm, therefore, one has to take into account the effects exerted by all parts of the system.

Since FSR represented an innovation within the GR -broadly defined-, let us ask where it came from; by what process did it emerge? The usual story told by experts in FSR is that it emerged in the 1960s and took off during the 1970s (e.g., Brush \& Turner, 1987). In 1964 the American soil scientist, Richard Bradfield, joined the International Rice Research Institute and argued that more attention needed to be paid to the needs of small farmers, in particular to their systems of cropping and the diversity of growing conditions in which they worked. Though initially ignored, by 1968 he had a small group working on multiple cropping, and there was recognition at IRRI that more work needed to be done on the ecological, social and economic environments in which rice was grown. In 1972, accordingly, IRRI established a Cropping Systems Program for him, and during the 1970s FSR took off as the approach was established at several national and regional institutes as well as at other international agricultural research centres. By the 1980s some felt that FSR had become a dominant concept (Tripp et al., 1990: 384).

This story attributes a great deal of significance to the work of a single individual without asking where he might have acquired some of his ideas. If we, however, extend our search for concepts resembling FSR back in time, one thing we find is that some of the ideas central to FSR were developed during the colonial period. Many years ago, Michael Worboys noted that during the 1930s the British colonial agricultural service began to shift away from a focus on single crops toward a concern with agricultural systems as a whole (Worboys, 1979: 369), and since then others have made similar observations (Tripp et al., 1990: 385; Maat, 2007; Maat \& Glover, 2012: 137-38). In principle this is not altogether surprising, for developing an understanding of a farming system requires a detailed knowledge of a particular place: its soils, climate, biotic environment, economy and culture. And unlike modern development experts, colonial agricultural officers were able to make successful careers despite being based in one place for many years, enabling them to acquire highly specialized and local knowledge (Mehos \& Moon). And as historians of colonial science have emphasised, knowledge and practice circulated back and forth between colonisers and colonized (e.g., Raj, 2007).

In India, for example, Albert Howard drew attention to the practice-common on peasant farms- of growing mixed crops on a single plot (intercropping), noting that the practice appeared to be effective even though orthodox agricultural science had paid it little 
attention (Marglin, 1996: 222). The situation in East Africa during the 1930s was similar (Belshaw, 1980). In colonial Senegal there are indications that French social scientists' understanding of local ecological conditions and respect for native practices may have informed the emergence there of an approach rather like FSR (Bonneuil, 1999: 283-85) ${ }^{19}$, and much the same has been said of the work in colonial Sumatra by the Dutch agronomist, M. B. Smits (Maat, 2015). Along similar lines, it may be no accident that following his experience of East African peasant agriculture during the 1950s, the anthropologically informed British economist, J. Leonard Joy, was arguing in the mid-1960s that a farmer's choice of technology could not be understood without taking into account the relevant farming system as a whole (Joy, 1969:377, emphasis in the original). Finally, perhaps the most interesting such case is that of Rene Dumont, the French agronomist with extensive interwar experience of colonial Indochina. In the 1950s his book Types of Rural Economy was an attempt to evaluate the possibilities of different types of agricultural practice -systems of agriculture as he called them (Dumont, 1957: VII-VIII)- based on case studies drawn from various developing countries as well as Europe. And such systems, he argued, embraced not only climate and soil but the economic, social, educational and legal settings in which farming was conducted.

The question arises, of course, whether the resemblance between this colonial work and FSR is merely an accident (a case of independent discovery) or whether past and present are genealogically connected. Some evidence suggests the latter. One prominent figure in the field today, for example, has observed in passing that quite a lot of work on FSR in the 1960s and '70s was done by scientists who had colonial experience (Collinson, 2000), and there is supportive evidence from the history of colonial development policy (Joseph Hodge, pers. comm.). Here, then, is a connection well worth exploring further.

Consider another example of an innovative approach to assisting small farmers which has attracted considerable attention since the 1970s: agroecology. Like FSR, agroecology focuses upon systems, in this case the ecological system in which cultivated plants and domestic animals interact with wild species, soil, and climate. But the central issue for agroecology is the reliance of industrial agriculture upon commercial inputs as well as the damage which it inflicts upon the environment. Thus agroecologists seek to strengthen peasant farming by increasing the productivity of existing cultivation methods in such a

19. During the 1950s, similarly, several of the French breeders who rejected the hybrid corn method in favour of alternative methods of maize improvement (which were designed to be less costly for smallholders) had previously worked in the French colonial agricultural service (BoNNEUIL \& THOMAs, 2009: 179-84). 
way as to make them more sustainable (both environmentally and economically) than those employed by the $\mathrm{GR}^{20}$.

When did this new approach emerge? In the development literature agroecology is generally portrayed as a post- 1945 phenomenon. Much of the early work contributing to the new discipline is said to have appeared in the $1950 \mathrm{~s}$, ' 60 s and ' 70 s. Some agroecological practices were introduced in the global South during the 1960s, but rapid expansion of the agroecological literature stems from the early '70s (Hecht, 1987) ${ }^{21}$. Latest by the 1980 s and '90s sustainability had become a central theme of development funding and programmes (Rist, 2008: 178).

Thus agroecology became visible in development circles since the 1960s, but how and where did it take shape as a body of knowledge and practice? A clue lies in the fact that, as its practitioners emphasise, agroecology is a hybrid discipline which draws not only upon ecological theory but also upon farmers' knowledge ${ }^{22}$. Its empirical basis is said to have been provided by the long-established cultivation systems in the global South which have remained productive, if at a modest level, for centuries ${ }^{23}$. Since these systems' longevity indicates that they are ecologically sustainable, they provide the ecologist with working models that are helpful in designing improved cultivation systems (Altieri, 2004). Thus the discipline "walks on two legs" which complement each other (Pimbert, 1994).

20. One example of such a method is integrated pest management which has sought to develop biological methods of pest control in order to reduce the reliance upon pesticides (CONWAY, 1999).

21. Gliessman sees Mexico in the latter 1970s as a major site where agroecology emerged in response to failures there of the GR (GLIESSMAN, 2013: 24) though the rise of environmental movements during the 1970s will also have played a role. The oil crisis of 1973-74, as Hecht notes, soon prompted studies which showed how energy-inefficient industrial agriculture was compared to other production systems with lower yields. That agroecology did not take off earlier may also have had something to do with the state of ecological theory, for it was during the 1960s that understanding of ecosystem structure and function made substantial progress (GLIESSMAN, 2013: 22).

22. Into the 1970s - and probably beyond- this fact posed a radical challenge to dominant assumptions among development experts. As Chambers noted, From rich-country professionals [...] to the lowliest extension workers, it is a common assumption that science-based knowledge is sophisticated, advanced and valid and, conversely, that whatever rural people may know will be unsystematic, imprecise, superficial and often plain wrong. [...] Knowledge flows in one direction only-downwards-from those who are strong, educated and enlightened towards those who are weak, ignorant and in darkness (1979: 1). In agroecology, by contrast, knowledge flows in the opposite direction. As Altieri puts it, the poor but efficient teaches the opulent but wasteful (1983: 404).

23. For example, biological control of pests has been documented in China ca. 300 BC, and European explorers observed the intercropping of maize, beans and squash in Central America in the $16^{\text {th }}$ century (DENEVAN, 1995). 
But what exactly does each partner contribute? According to agroecologists, it is farmers' knowledge -of particular ecological settings and the kinds of practices which work there- which provides agroecology with an essential empirical foundation precisely because ecologists rarely possess such knowledge (Gliessman, 2013: 22-4). Moreover, since every traditional agroecosystem has a specific character, agroecologists do not attempt to focus on the particularities of each one but look instead for the underlying ecological principles common to many of them (Altieri, 2004). Thus they draw upon ecological theory in order to account for the sustainable success of such systems. And once an agroecosystem has been understood in this way, the aim is to use theory to improve upon existing farming methods ${ }^{24}$.

This presents a neat division of labour, but it is doubtful whether the farmer's role is adequately described as providing merely an "empirical" foundation. For one thing, existing cultivation systems are not simply open for inspection by the ecologist who can take away such "data"; they presumably need to be interpreted by the farmer: e. g., why a given crop is planted early or late, why seed is planted at a particular depth or spacing, why a certain form of intercropping is used, etc. For another, the choice of a particular cultivation-system only makes sense against the backdrop of experience. The farmer knows from his/her own experience (via informal experiments) as well as from that of previous generations which cultivation practices have been tried in a given location and failed. Thus a cultivation system is not self-explanatory; for the ecologist to acquire more than a superficial understanding of the system, he/she needs the farmer to explain the meaning of the data and how it was obtained ${ }^{25}$.

As a discipline, therefore, agroecology represents a fusion of knowledge and practice from both South and North. But how did these two bodies of knowledge encounter one another in the first place? Again there are hints in the literature suggesting that the colonial agricultural service was one such site. We know, for example, that the agroecological approaches to plant breeding pursued in both Sri Lanka and Bengal in the 1950s had been developed in both places between the wars (Pain, 1986). Furthermore, during the 1930s some ecologists in Northern Rhodesia were impressed by the fact that peasant farmers took their environment into account when devising cultivation methods (Speek, 2014). And among the early pioneering work by anthropologists on indigenous agriculture sys-

24. Improving them is evidently not easy. HECHT (1987) remarks in passing that agroecologists have often done little more than explain the basis of the techniques devised by farmers.

25. In Fan's study of the fieldwork of British naturalists in China during the $19^{\text {th }}$ century, he notes that it was crucial, not just to collect plant specimens, but also to learn from Chinese gardeners what kind of soil/water/temperatures were necessary for a species to survive as well as how it was cultivated (FAN, 2007: 219-20). 
tems was Audrey Richards' 1939 study of the composting methods used by a Central African tribe (Hecht, 1987).

As with the evidence for the colonial origins of FSR, of course, the evidence for agroecology is fragmentary but nonetheless promising enough to deserve further study because it could illuminate more precisely how the circulation of people and practices can generate new knowledge. Despite the social and cultural obstacles which undoubtedly hinder communication and learning between southern farmers and northern experts, therefore, the evidence points toward particular circumstances where these may have been overcome, paving the way for major innovation.

\section{WHO GAINED?}

As well as having been an important source of innovation, the global circulation of plants, people and practices has also been of major economic significance. Most discussions of the economic impact of the GR, of course, have focussed on the global South where it has undoubtedly been important. Yield-increases (in wheat, for example, of two to threefold) led to greatly increased cereals-production, allowing Asian governments to stop importing grain and to provide cheaper food for urban workers. But we know much less about the GR's impact on northern economies. Before attempting to assess the scale of this impact, let us step back and place the GR in a wider context, considering two older and more general processes which have connected global North and South.

One of these, the transfer of crop species from one hemisphere to another, has been going on for several thousand years. Following the Columbian Exchange, northern interests have been especially keen to gain access to southern plant resources. Since the $19^{\text {th }}$ century, for example, the US Department of Agriculture has organised prospecting expeditions in search of agriculturally or medically valuable plants which have paid off handsomely. In the 1930s, for example, two of its staff brought back several soybean varieties from China which became a mainstay of the US soybean industry after 1945. The expedition cost $\$ 50,000$, but the value of the US industry by 1950 was approximately one billion dollars (McCann, 1950: 51). Such transfers, continuing into the present, are sometimes termed biopiracy since material is often collected without the permission of southern governments or compensation to farmers (Kloppenburg, 1988; Flitner, 1995; Pistorius \& Van Wijk, 1999).

Another perspective from which the GR may be viewed is to see it as just one example of development aid from North to South since about 1945. And it is well-established 
that much development aid from northern donors has been granted on the condition that the recipient would use the loan to purchase northern services or equipment (tied aid). This is why, for example, northern fertiliser companies were enthusiastic about the GR, sometimes serving on donors' advisory committees (Unger, 2010), and the same can evidently be said about American tractor companies (Biggs \& Justice, 2015: 24-5). One consequence of this system, as an executive director of the World Bank noted in 1980, is that for every dollar lent by the Bank seven dollars came back to firms in industrialised countries (Goldman, 2005: 298). More generally, the evidence suggests that the scale of development aid is very small in relation to the huge flows of capital from South to North (Tribe, 1991; Hickel, 2013). As the Australian Minister of Primary Industries and Energy put it, Let me emphasise that aid is not a question of charity ${ }^{26}$. While aid workers themselves may be motivated by humanitarian concerns, therefore, one cannot ignore the fact that for northern governments and interest groups it is often the prospect of a commercial payoff which makes development aid seem sensible.

Against this backdrop, let us return to the GR and consider what is known about the economic value of high-yielding varieties in the North. Given the scale of maize-growing in the US, for example, it is not surprising that breeders there were keen to gain access to the enormous diversity of traditional maize varieties in Latin America. The Rockefeller Foundation's GR program in Mexico, for example, began to collect Mexican varieties on a small scale from 1943. By the late '40s a seed company in Iowa was collaborating with Iowa State University to set up a maize research project in Guatemala. As the firm's president explained, experience has taught us not to confine our search [for disease-resistant varieties] exclusively to [the US] (quoted in Kloppenburg, 1988: 159). And in 1951, as new work by Helen Curry demonstrates (Curry, 2016; cf. Chang, 1979: 94), a Committee on the Preservation of Indigenous Strains of Maize was established under the auspices of the US National Research Council, obtained funding from the Department of State, and enjoyed a cooperative arrangement with RF breeding projects in Mexico and Colombia. Loss of these varieties, the Committee argued, would undermine efforts to improve maize not only in Latin America but also in the US. Accordingly, the Committee requested that in addition to depositing collected materials in regional storage centres in Mexico, Brazil and Colombia, samples of each variety were to be sent to a "stand-by" storage facility at a US Department of Agriculture site in Maryland. Although the collection was allegedly intended in part for the improvement of Latin American maize, all of the members of the Committee were US American: eight academics and/or museum staff, two scientists from the US Department of Agriculture, and one breeder from the private firm, Pioneer HiBred (Curry, pers. comm.). In view of the huge expansion of private-sector maize-breed-

26. John Kerin, speech to World Food Day 1990, quoted in TRIBE (1991: 46). 
ing in the US during the 1930s and "40s (Fitzgerald, 1990), it seems virtually certain that US breeders and firms will have benefitted from these collections, though the scale of that gain remains to be established.

Better quantitative data, however, exists on the importance of GR wheat and rice varieties to US agriculture. In 1984 about twenty percent of the US wheat acreage was planted in varieties whose ancestry came either from the Rockefeller's Mexican GR programme or its successor, the International Centre for Maize and Wheat Improvement (CIMMYT). And of the ten leading wheat varieties in the US in 1984, four had CIMMYT ancestry (Dalrymple, 1986a: 34,96$)^{27}$. Although rice is a much less important crop in the United States, US growers have also benefitted from work conducted at the International Rice Research Institute and from southern breeders more generally. In performance trials in Texas and Louisiana, for example, breeders found that the highest yielding varieties were from Taiwan and from IRRI itself (Athwal, 1971:23). As a result US growers soon shifted to growing short varieties, and by the 1980s three-quarters of this acreage was planted in varieties with IRRI ancestry (Dalrymple, 1986b: 113-15).

What, then, has been the economic payoff of GR varieties for the US? A study by the International Food Policy Research Institute estimated the economic contribution of these wheat varieties to US agriculture over the period 1970 to 1993 (Pardey et al., 1996). In the case of rice it found that the economic benefit of GR varieties was up to one billion dollars (compared to US investment in the relevant research of 63 million dollars), meaning a benefit-cost ratio as high as 17 . In the case of wheat, the economic gain was up to 13.7 billion dollars (on an investment in research of 71 million dollars), yielding a benefit-cost ratio as high as 190 . As the authors conclude, Overall, the U. S. economy reaps enormous rewards from the nation's investments in international agricultural research (Pardey et al., 1996: 13) ${ }^{28}$. In order to be able to evaluate the significance of these gains to the US economy, of course, we need to make the same kind of calculation for those developing countries where wheat and rice are central to the diet. As far as GR rice varieties are concerned, the gains to both Chinese and Indian agriculture have been estimated at ten times the cost of the research to them (Fan et al., 2005: 375, 378). While

27. Staff at Rockefeller's Mexican programme seem to have been fully aware of US interests. New varieties of wheat developed by the programme were sent to the US Department of Agriculture for testing. If they did not meet the demands of US food processors, they were eliminated from further development (JENNINGS, 1988: 85).

28. The aim of these authors' analysis, to be sure, was not to expose the self-interested character of northern funding for international agricultural research but rather to persuade northern politicians to fund it more generously. 
relatively high ${ }^{29}$, therefore, the scale of this payoff is still substantially less than that to the US.

The other northern country for which economic data exist is Australia. Given its own tropical and semi-tropical agricultural regions, it made sense for Australia to maintain close ties to some international agricultural research institutes, and that has paid off. Within a decade of obtaining a pasture legume from the International Centre for Tropical Agriculture (Colombia), for example, Australian farmers had planted it on half a million hectares (Tribe, 1991: 45). By 1990 three-quarters of Australia's wheat acreage had been planted in high-yielding varieties derived from material obtained in 1974 from the International Centre for Maize and Wheat Improvement (Mexico). The economic gain from increased production over that period was conservatively estimated to be two billion dollars (Tribe, 1991: 46) which was 220 times the amount of Australia's funding for that institute (ibid.: 59). As the author concludes, the benefits accruing to Australia [from aid] have [...] been enormous (ibid.: 12).

The global circulation of plants, people and practices, therefore, has had very considerable economic consequences for both hemispheres. As with development aid more generally, however, it appears that the GR's payoff to the global North may have been substantially greater than gains to the South.

\section{CONCLUSION}

In the media development aid is often implicitly portrayed as a gift from the "generous" North to the impoverished South (Hickel, 2016). But as I have argued here, when one examines the process of circulation in the GR, this view does not stand up. For one thing, the GR was not simply devised in the North and transferred to the South. As we have seen, the GR's high-yielding varieties depended heavily upon parental germplasm which had been previously developed in the South, by breeders as well as farmers ${ }^{30}$. Moreover two novel approaches to boosting small farm productivity which began to appear on the de-

29. By comparison, estimates of the gain to US agriculture from public-sector agricultural research in the US vary between about $20 \%$ and $100 \%$ (RUTTAN, 1980) while in the UK the corresponding estimates for the period 1953 through 1990 were about 20\% (THIRTLE et al., 1997). One World Bank review in 1987 of about one hundred of its projects in the global South found an average rate of return of 17\% (TRIBE, 1991: 23).

30. Although the fact that most GR rice and wheat varieties originated in the global South has been known for many years (e.g., DALRYMPLE, 1977: 181), its significance for our understanding of the GR has been overlooked. 
velopment agenda from the 1970s had arisen out of encounters between northern experts and southern farmers in which the former had not dismissed the latter as "backward" but sought instead to learn from them.

Nor can the GR be regarded merely as a humanitarian undertaking. For the evidence suggests that northern agriculture and firms have gained very substantially from development aid in general and from the GR in particular. Rather than portraying the GR as a "gift", therefore, it is more accurate to regard the North as having invested in research nominally designated for the South with the aim of reaping a hefty return. These findings suggest that future studies of the GR ought to explore to what extent the exploitative relations between North and South so characteristic of colonialism have in fact been perpetuated into the present.

\section{ACKNOWLEDGEMENTS}

My thanks to Harro Maat for commenting on a draft of this paper and to Dominic Glover for originally suggesting to me that the circulation of plants and practices is an interesting and important phenomenon. I am also indebted to Dr. Dana Dalrymple, formerly of USAID, for generously sharing with me several valuable but little known articles on dwarf wheat varieties. Lastly, I thank the journal's two reviewers, several of whose comments were helpful in improving the paper.

Since leaving Manchester in 2014, it would have been exceedingly difficult to continue my research, had it not been for the invaluable support I have enjoyed in Brighton and Berlin: from Johan Schot (director, Science Policy Research Unit, Sussex University), Jim Sumberg (leader, Rural Futures Cluster, Institute for Development Studies, Sussex University), and Dagmar Schaefer (department head and director, Max-Planck Institute for History of Science, Berlin) as well as from their excellent library staffs.

This paper was initially presented as open lecture at the Plenary Session Global circulation of species and biological innovation, 16th-20th centuries: landscapes, production and consumption, by J. Pujol-Andreu, J. M. Pacheco and A. Polónia, A. (Coords.), at the VI Rural RePort Meeting/XV Congreso de Historia Agraria de la SEHA, "Old and New Worlds: the Global Challenges of Rural History” (Lisbon, 28-30 January 2016). 


\section{REFERENCES}

Altieri, M. A. (1983). The Question of Small Farm Development: Who teaches whom? Agriculture, Ecosystems \& Environment, 9 (4), 401-5.

Altieri, M. A. (2004). Linking Ecologists and Traditional Farmers in the Search for Sustainable Agriculture. Frontiers in Ecology and the Environment, 2 (1), 35-42.

ANDERson, R. S., Levy, E. \& Morrison, B. M. (1991). Rice Science and Development Politics: Research Strategies and IRRI's Technologies Confront Asian Diversity (19501980). Oxford: Clarendon.

AsH, E. (2010). Introduction: Expertise and the Early Modern State. In Expertise: Practical Knowledge and the Early Modern State (pp. 1-24). Chicago: University of Chicago Press.

Athwal, D. S. (1971). Semidwarf Rice and Wheat in Global Food Needs. The Quarterly Review of Biology, 46 (1), 1-34.

Baranski, M. R. (2015). The Wide Adaptation of Green Revolution Wheat. PhD Thesis. Tempe: Arizona State University.

BARKer, R. \& HERDT, R. W. (1982). Setting Priorities for Rice Research in Asia. In R. S. ANDerson et al. (Eds.), Science, Politics and the Agricultural Revolution in Asia (pp. 427-61). Boulder: Westview.

BARker, R., HerdT, R. W. \& Rose, R. (1985). The Rice Economy of Asia. Washington, DC: Resources for the Future/The International Rice Research Institute.

BeINART, W., BRown, K. \& Gilfoyle, D. (2009). Experts and Expertise in Colonial Africa Reconsidered: Science and the Interpenetration of Knowledge. African Affairs, 108 (432), 413-33.

BeLL, M. (1979). The Exploitation of Indigenous Knowledge or the Indigenous Exploitation of Knowledge: Whose Use of What for What? IDS Bulletin, 10 (2), 44-50.

BeLshaw, D. (1980). Taking Indigenous Technology seriously: The Case of Inter-Cropping Techniques in East Africa. In D. BROKENSHA, D. M. WARREN \& O. WerNER (Eds.), Indigenous Knowledge Systems and Development (pp. 195-201). Washington, DC: University Press of America.

Biggs, S. \& Justice, S. (2015). Rural and Agricultural Mechanisation: A History of the Spread of Small Engines in Selected Asian Countries. IFPRI Discussion Paper, (1443).

BonneuIL, C. (1999). Penetrating the Natives: Peanut-Breeding, Peasants and the Colonial State in Senegal (1900-1950). Science, Technology and Society, 4 (2), 273-302.

Bonneuil, C. \& Thomas, F. (2009). Gènes, pouvoirs et profits: Recherche publique et régimes de production des savoirs de Mendel aux OGM. Versailles/Lausanne: Quae/Fondation pour le progrès de l'homme. 
BRush, S. B. \& TURNER, B. L. (1987). The Nature of Farming Systems and Views of their Change. In B. L. TURNER \& S. B, Brush (Eds.), Comparative Farming Systems (pp. 11-48). New York: Guilford.

CHAmbers, R. (1979). Editorial. IDS Bulletin, 10 (2), 1-3.

Chang, T. T. (1979). Crop Genetic Resources. In J. SNEEP \& A. J. T. Hendriksen (Eds.), Plant Breeding Perspectives (pp. 83-103). Wageningen: PUDOC.

Collins, H., Evans, R. \& Gorman, M. E. (2010). Trading Zones and Interactional Expertise. In M. E. Gorman (Ed.), Trading Zones and Interactional Expertise (pp. 7-23). Cambridge: MIT Press.

Collinson, M. (2000). My FSR Origins. In M. Collinson (Ed.), A History of Farming Systems Research (pp. 34-9). Wallingford/Roma: CABI/Food and Agriculture Organization of the United Nations.

Conway, G. (1999). The Doubly Green Revolution. Ithaca: Comstock.

CotTer, J. (2003). Troubled Harvest: Agronomy and Revolution in Mexico, 1880-2002. Westport/London: Praeger.

Curry, H. A. (2016). Breeding Uniformity and Banking Diversity: The Genescapes of Industrial Agriculture, 1935-1970. Unpublished paper. University of Cambridge.

D'Amato, F. (1989). The Progress of Italian Wheat Production in the First Half of the $20^{\text {th }}$ Century: The Contribution of Breeders. Agricoltura Mediterranea, (119), 157-74.

DALRYMPLE, D. G. (1977). Evaluating the Impact of International Research on Wheat and Rice Production in the Developing Nations. In T. M. ARndt, D. DALRYMPLE \& V.W. RutTAN (Eds.), Resource Allocation and Productivity in National and International Agricultural Research (pp. 171-208). Minneapolis: University of Minnesota Press.

Dalrymple, D. G. (1986a). Development and Spread of High-Yielding Wheat Varieties in Developing Countries. Washington, DC: Agency for International Development.

Dalrymple, D. G. (1986b). Development and Spread of High-Yielding Rice Varieties in Developing Countries. Washington, DC: Agency for International Development.

DalRYMPLE, D. G. (1988). Changes in Wheat Varieties and Yields in the United States, 1919-1984. Agricultural History, 62 (4), 20-36.

Denevan, W. M. (1995). Prehistoric Agricultural Methods as Models for Sustainability. Advances in Plant Pathology, (11), 21-43.

Dumont, R. (1957). Types of Rural Economy: Studies in World Agriculture. London: Methuen.

FAN, F. (2007). Science in Cultural Borderlands: Methodological Reflections on the Study of Science, European Imperialism and Cultural Encounter. East Asian Science, Technology and Society, 1 (2), 213-31.

Fan, F. (2012). The Global Turn in the History of Science. East Asian Science, Technology and Society, 6 (2), 249-58. 
FAN, S. et al. (2005). National and International Agricultural Research and Rural Poverty: The Case of Rice Research in India and China. Agricultural Economics, 33 (3), 369-79.

Fitzgerald, D. (1990). The Business of Breeding: Hybrid Corn in Illinois, 1890-1940. Ithaca: Cornell University Press.

FLITNER, M. (1995). Sammler, Räuber und Gelehrte: Die politischen Interessen an pflanzengenetischen Ressourcen 1895-1995. Frankfurt: Campus.

Francks, P. (1984). Technology and Agricultural Development in Pre-War Fapan. New Haven:Yale University Press.

FreEman, C. (1994). The Economics of Technical Change. Cambridge fournal of Economics, 18 (5), 463-514.

FreY, M. \& KunKel, S. (2011). Writing the History of Development: A Review of the Recent Literature. Contemporary European History, 20 (2), 215-32.

Galison, P. (1997). Image and Logic: A Material Culture of Microphysics. Chicago: University of Chicago Press.

Gliessman, S. (2013). Agroecology: Growing the Roots of Resistance. Agroecology and Sustainable Food Systems, (37), 19-31.

Glover, D. (2013). Tracing the Roots of the "Root Revolution": Exploring the Origins of the System of Rice Intensification. 24 International Congress of History of Science, Technology and Medicine. Manchester: University of Manchester.

Goldman, M. (2005). Imperial Nature: The World Bank and Struggles for Social Fustice in the Age of Globalization. New Haven:Yale University Press.

Gorman, M. E. (2010). Introduction. In M. E. Gorman (Ed), Trading Zones and Interactional Expertise. Cambridge: MIT Press.

HABERMAS, R. (2013). Intermediaries, Kaufleute, Missionare, Forscher und Diakonissen: Akteure und Akteurinnen im Wissenstransfer Einfuehrung. In R. HABERMAS \& A. PrZYrembel (Eds), Von Käfern, Märkten und Menschen: Kolonialismus und Wissen in der Moderne (pp. 27-48). Göttingen:Vandenhoeck \& Ruprecht.

Habermas, R. \& Przyrembel, A. (2013). Von Käfern, Märkten und Menschen. Göttingen: Vandenhoeck \& Ruprecht.

HaRwood, J. (2012). Europe's Green Revolution and Others Since: The Rise and Fall of Peasant-Friendly Plant-Breeding. London: Routledge.

HaRwood, J. (2013). Has the Green Revolution been a Cumulative Learning Process? Third World Quarterly, 34 (3), 397-404.

Hecht, S. B. (1987). The Evolution of Agroecological Thought. In M. A. Altieri (Ed.), Agroecology: The Scientific Basis of Alternative Agriculture (pp. 1-20). Boulder:Westview Press. 
HiCKel, J. (2013). The Donors' Dilemma: Aid in Reverse: How Poor Countries develop Rich Countries. http://www.globalpolicyjournal.com/blog/12/12/2013/donors\%E2\% 80\%99-dilemma-aid-reverse-how-poor-countries-develop-rich-countries

Hickel, J. (2016). Does the West really care about Development? https://www.theguardian.com/global-development-professionals-network/2016/mar/05/does-westcare-development

Hodge, J. M. (2010). British Colonial Expertise, Post-Colonial Careering and the Early History of International Development. Fournal of Modern European History, 8 (1), 2445.

IORI, L. (2011). Electrical Hybrids. In G. PANCALDI (Ed.), Electricity and Life: Episodes in the History of Hybrid Objects. Bologna: Università di Bologna.

JaIN, H. K. (2010). Green Revolution: History, Impact and Future. Houston: Studium Press.

Jennings, B. H. (1988). Foundations of International Agricultural Research: Science and Politics in Mexican Agriculture. Boulder: Westview Press.

Joy, J. L. (1969). Diagnosis, Prediction and Policy Formulation. In C. R. WharTon (Ed.), Subsistence Agriculture and Economic Development (pp. 376-81). Chicago: Aldine.

KinARA, H. (1983). Origin and History of "Daruma", a Parental Variety of Norin 10. In S. SAKAмото (Ed.), Proceedings of the Sixth International Wheat Genetics Symposium (pp. 13-19). Kyoto: Kyoto University.

KLEIN, U. (2012). Introduction: Artisanal-Scientific Experts in $18^{\text {th }}$ Century France and Germany. Annals of Science, 69 (3), 303-6.

Kloppenburg, J. R. (1988). First the Seed:The Political Economy of Plant Biotechnology, 1492-2000. Cambridge: Cambridge University Press.

KRAFT, A. (2004). Pragmatism, Patronage and Politics in English Biology: The Rise and Fall of Economic Biology 1904-1920. Fournal of the History of Biology, 37 (2), 21358.

LIN, J. (2015). Sowing Seeds and Knowledge: Agricultural Development in Taiwan and the World, 1925-1975. East Asian Science, Technology and Society, 9 (2), 127-49.

Long, P. O. (2015). Trading zones in early modern Europe. Isis, 106 (4), 840-47.

Maat, H. (2001). Science Cultivating Practice: A History of Agricultural Science in the Netherlands and its Colonies, 1863-1986. Wageningen: Ponsen \& Looijen.

MAAT, H. (2007). Is Participation rooted in Colonialism? Agricultural Innovation Systems and Participation in the Netherlands Indies. IDS Bulletin, 38 (5), 50-60.

MaAt, H. (2015). Commodities and Anti-Commodities: Rice on Sumatra, 1915-1925. In F. Bray, P. A. Coclanis, E. L. Fields-Black \& D. SchäFer (Eds.), Rice: Global Networks and New Histories (pp. 335-54). New York: Cambridge University Press. 
MaAt, H. \& Glover, D. (2012). Alternative Configurations of Agronomic Experimentation. In J. SumBerg \& J.THOMPSON (Eds.), Contested Agronomy (pp. 131-45). London: Routledge.

MARGLIN, S. A. (1996). Farmers, Seedsmen and Scientists: Systems of Agriculture and Systems of Knowledge. In F. ApFFEL-MARglin \& S. A. MARglin (Eds.), Decolonizing Knowledge: From Development to Dialogue (pp. 185-248). Oxford: Clarendon.

Matchetт, K. (2006). At Odds over Inbreeding: An Abandoned Attempt at Mexico/United States Collaboration to "Improve" Mexican Corn, 1940-1950. Fournal of the History of Biology, 39 (2), 345-72.

MCCANN, L. P. (1950). The World is our Nursery. Foreign Agriculture, 14 (3), 51-5.

McCook, S. (2002). States of Nature: Science, Agriculture and Environment in the Spanish Caribbean, 1760-1940. Austin: University of Texas Press.

Menos, D. C. \& Moon, S. M. (2011). The Uses of Portability: Circulating Experts in the Technopolitics of Cold War and Decolonization. In G. HechT (Ed.), Entangled Geographies (pp. 43-74). Cambridge: MIT Press.

Ohno, K. \& Ohno, I. (1998). Fapanese Views on Economic Development: Diverse Paths to the Market. London: Routledge.

PaIN, A. (1986). Agricultural Research in Sri Lanka: An Historical Account. Modern Asian Studies, 20 (4), 755-78.

Pardey, P. G., Alston, J. M., Christian, J. E. \& Fan, S. (1996). Hidden Harvest: US Benefits from International Research Aid. Washington, DC: International Food Policy Research Institute.

Percival, J. (1921). The Wheat Plant: A Monograph. New York: E. P. Dutton.

Perkins, J. H. (1997). Geopolitics and the Green Revolution:Wheat, Genes and the Cold War. New York: Oxford University Press.

Pimbert, M. (1994). The Need for another Research Paradigm. Seedling, (11), 20-25. Pistorius, R. \& VAN Wijk, J. (1999). The Exploitation of Plant Genetic Information: Political Strategies in Crop Development. Wallingford: CABI.

Pratt, M. L. (1991). Arts of the Contact Zone. Profession, (1991), 33-40.

RAJ, K. (2007). Relocating Modern Science: Circulation and the Construction of Scientific Knowledge in South Asia and Europe, 1650-1900 Centuries. New York: Palgrave Macmillan.

RaJ, K. (2013). Beyond Postcolonialism... and Postpositivism: Circulation and the Global History of Science. Isis, 104 (2), 337-47.

REITZ, L. P. (1968). Short Wheats stand Tall. Yearbook of Agriculture, (1968), 236-39.

RichARDS, P. (1997). Toward an African Green Revolution? An Anthropology of Rice Research in Sierra Leone. In A. E. Nyerges (Ed.), The Ecology of Practice (pp. 201-52). Amsterdam: Gordon \& Breach. 
RIst, G. (2008). The History of Development: From Western Origins to Global Faith. London: Zed Books.

RoBERTS, L. (2009). Situating Science in Global History: Local Exchanges and Networks of Circulation. Itinerario, (33), 9-30.

Ross, C. (2014). The Plantation Paradigm: Colonial Agronomy, African Farmers, and the Global Cocoa Boom, 1870s-1940s. Fournal of Global History, 9 (1), 49-71.

RutTan, V. (1980). Bureaucratic Productivity: The Case of Agricultural Research. Public Choice, (35), 529-47.

SECORD, J. (2004). Knowledge in Transit. Isis, 95 (4), 654-72.

Sivasundaram, S. (2010). Sciences and the Global: On Methods, Questions and Theory. Isis, (101), 146-58.

SpeEk, S. (2014). Ecological Concepts of Development? The Case of Colonial Zambia. In J. M. Hodge, G. Hödl \& M. Kopf (Eds.), Developing Africa: Concepts and Practices in Twentieth-Century Colonialism (pp. 133-54). Manchester: Manchester University Press.

Thirtle, C., Palladino P., \& Piesse J. (1997). On the Organisation of Agricultural Research in the United Kingdom, 1945-1994: A Quantitative Description and Appraisal of Recent Reforms. Research Policy, (26), 557-76.

TRIBE, D. E. (1991). Doing Well by Doing Good:Agricultural Research: Feeding and Greening the World. Leichardt/Parkville: Crawford Fund for International Agricultural Research/Pluto Press.

Tripp, R., Anandajayasekeram, P., Byerlee, D. \& Harrington, D. (1990). Farming Systems Research Revisited. In C. K. EICHER \& J. M. StAATZ (Eds.), Agricultural Development in the Third World (pp. 384-99). $2^{\text {nd }}$ Ed. Baltimore: Johns Hopkins University Press.

Turchetti, S., Herran, N. \& Boudia, S. (2012). Introduction: Have we ever been "Transnational"? Towards a History of Science across and beyond Borders. British Fournal for the History of Science, 45 (3), 319-36.

Unger, C. R. (2010). Industrialization vs. Agrarian Reform: West German Modernization Policies in India in the 1950s and 1960s. Fournal of Modern European History, 8 (1), 47-65.

Willis, K. (2006). Norman Borlaug. In D. SimON (Ed), Fifty Key Thinkers on Development (pp. 45-50). London: Routledge.

Worboys, M. (1979). Science and British Colonial Imperialism, 1895-1940. PhD Thesis. Brighton: University of Sussex. 